NEWS IN BRIEF

\section{Merger plan dropped}

\section{London}

JOHN MacGregor, the UK Secretary of State for Education and Science, has decided not to set up a working group to consider the possibility of a merger between the Agricultural and Food Research Council (AFRC) and the Natural Environment Research Council. The Advisory Board for the Research Councils (ABRC) recommended to MacGregor in a letter on 1 December that a small group under ABRC should examine the idea of a closer association between the two research councils, as a way of eliminating turf-battles over responsibilities for environmental science, and especially land use research.

MacGregor's reply notes that the streamlined ABRC, which will start work on 1 April (see Nature 343, 294; 1990), has been set up to improve cooperation among all five research councils within the existing research council structure, a matter to which he expects the new board "to give urgent attention".

P.A.

\section{Alternative on loans}

\section{London}

THE UK Committee of Vice-Chancellors and Principals (CVCP) this week unveiled an alternative to the government's student 'top-up loans' scheme. The CVCP proposes that students should receive an adequate grant, not means-tested against parental income, but should pay a 'graduate tax', once their income is higher than the national average.

The government's scheme aims to keep the present maintenance grant with a contribution from parents, dependent on income. But the grant would be frozen at its current level, and supplemented progressively with centrally provided loans.

The CVCP says that it is willing to run its scheme, which, it claims, would be cheaper to run than the government's proposals. Universities would provide grants, and be reimbursed by the Department of Education and Science, either directly or through the Universities Funding Council.

A spokesman for the CVCP says that, in view of the difficulties the government is having in setting up its student loans company, following the major banks' refusal to become involved, the time is right to consider alternatives. But the CVCP's scheme may be unacceptable to the government, which has stated previously its opposition to any kind of graduate tax.

\section{Old flames}

A FIRE destroying the "fine buildings" of the University of Toronto was in the news this week, 100 years ago. Ten years ago, President Carter was easing back on the US commitment on fast-breeder reactors. See the Then and Now page, facing the inside back cover.

\title{
Marshall pulls no punches
}

\section{London}

BLAME for the abandonment of the British pressurized water reactor (PWR) programme rests with the British government, according to Lord Marshall, former chairman of the Central Electricity Generating Board (CEGB). He was giving evidence to the House of Commons Select Committee on Energy last week.

Marshall said the particular formula chosen for the financial structure of the privatized electricity industry had led to escalating estimates of the cost of nuclear power and the subsequent scrapping of plans to build further PWR generating plant (see Nature 342, 213; 1989).

The sale to public shareholders will begin in April, when twelve distribution companies will be sold. Privatization of the National Grid and of nationalized generating plant (in three parcels, one in Scotland and two in England and Wales) will follow next year.

Marshall contrasted the British plan with arrangements in the United States and Japan, where generating companies hold a franchise for a geographical area in return for an 'obligation to supply'. The crucial question, he said, was British government's original plan to place the obligation to supply with the distribution

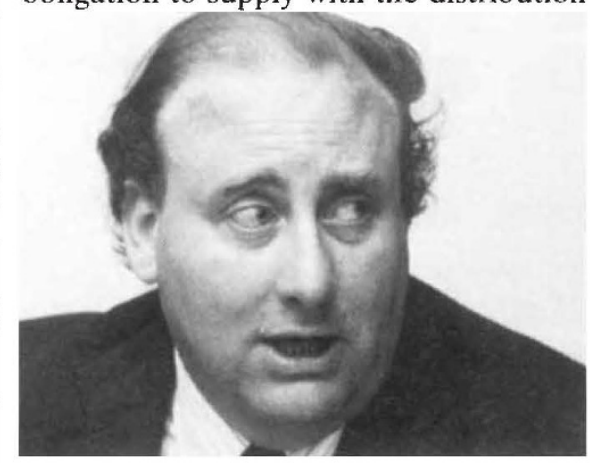

Marshaii: No looking back

companies, holding regional franchises, but with no long-term obligations to the generators.

At that stage, Marshall said, he had thought privatization of the nuclear industry was "difficult, but not impossible". But when the government later chose to allow free competition between distributors, removing the obligation to supply, successful privatization of nuclear plants became impossible.

The government "should have been aware ... that they were going to make life very difficult for nuclear power", Marshall said. The final form of privatization meant that the distributors would not have signed long-term contracts for nuclear generated electricity with National Power (the company to have taken over Britain's nuclear generating capacity). But without long-term contracts or government guarantees, the large initial capital costs of PWR reactors would have to be recouped over a much shorter period than their operating life, inflating short-term costs.

The need to make a competitive rate of return on invested capital in the private sector (about 10 per cent a year, rather than the 5 per cent demanded by government during most of the 1980s), Marshall said, had also increased cost of nuclear power.

But Marshall admitted that, even if the electricity industry had been privatized as he had wanted, PWRs might still have been more expensive in the short term than gas turbine power stations. "In my view, we would have built nuclear plants and gas turbines simultaneously", he said.

Asked if he could have been more helpful to the government during the build-up to privatization, Marshall regretted he had been "too amenable".

Marshall also attacked the management of Britain's nuclear programme by successive governments, in particular the decision to develop advanced gas-cooled reactors (AGRs).

But Marshall, himself, was criticized during questioning for failing to obtain "substantive discussions" on the privitization of nuclear plants with the Department of Energy, during the early stages of privatization. Marshall answered that Department officials had been busy with the non-nuclear side of privatization during 1988 and the early part of 1989. Discussions were also delayed until CEGB had received figures from British Nuclear Fuels for fuel reprocessing costs.

Increases in these reprocessing costs were blamed by Marshall for the spiralling estimates of the cost of decommissioning Britain's ageing Magnox reactors, responding to suggestions that only privatization had forced CEGB to reveal the true costs of decommissioning.

Marshall explained that a shut-down Magnox reactor contained the equivalent of 8 year's fuel. British Nuclear Fuels traditionally had a 'cost-plus' contract with CEGB, where any increased costs, for example due to environmental safety improvements, were simply charged to CEGB. As privatization approached, British Nuclear Fuels was forced to give fixed-price quotes for reprocessing, which were set at a high level to cover future cost increases.

Despite this, Marshall said he had been surprised at the government's initial decision in July 1989 to remove Magnox stations from privatization (before the decision to retain all nuclear plants in public ownership). The most natural decision, he believed, would have been to retain the fuel cycle in the public sector and privatize the reactors. Peter Aldhous 